\begin{tabular}{c} 
Volume and Issues Obtainable at Center for Sustainability Research and Consultancy \\
Journal of Accounting and Finance in Emerging Economies \\
ISSN: 2519-0318 ISSN (E) 2518-8488 \\
Volume 7: Issue 1 March 2021 \\
CSRC \\
Journal homepage: www.publishing.globalcsrc.org/jafee \\
\hline
\end{tabular}

\title{
The Influence of Service Quality, Price and Environment on Customer Loyalty in the Restaurant's Industry: The Mediating Role of Customer Satisfaction
}

\begin{tabular}{|c|c|}
\hline \multicolumn{2}{|c|}{ 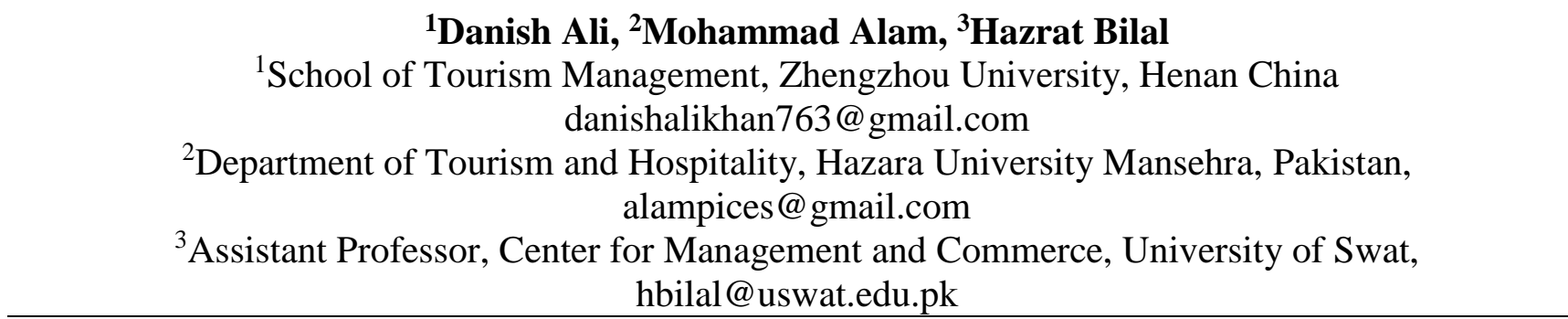 } \\
\hline ARTICLE DETAILS & ABSTRACT \\
\hline $\begin{array}{l}\text { History } \\
\text { Revised format: February } \\
2021 \\
\text { Available Online: } \text { March } \\
2021\end{array}$ & $\begin{array}{l}\text { The purpose of this research is to examine the influence of service } \\
\text { quality (SQ), Price (P) and Restaurant Environment (RE) on } \\
\text { customer loyalty (LOY), via the mediating role of customer } \\
\text { satisfaction (SAT) in the context of the restaurant industry in the } \\
\text { capital city of Pakistan (Islamabad). Five hundred questionnaires }\end{array}$ \\
\hline $\begin{array}{l}\text { Keywords } \\
\text { service quality, Price, } \\
\text { restaurant environment, } \\
\text { Customer Satisfaction, } \\
\text { Customer loyalty }\end{array}$ & $\begin{array}{l}\text { were distributed at various restaurants in a different location at } \\
\text { Islamabad, and } 385 \text { were returned. Multiple Regression Analysis } \\
\text { was used to test hypothesis relationships. The outcome of this } \\
\text { research shows that SQ, Pand RE have a positive association with } \\
\text { the SAT. In contrast, customer satisfaction also leads to customer }\end{array}$ \\
\hline $\begin{array}{l}\text { JEL Classification: } \\
M 40, M 48\end{array}$ & $\begin{array}{l}\text { loyalty. Moreover, customer satisfaction significantly mediates the } \\
\text { association among SQ, P, RE, and customer loyalty. The restaurant } \\
\text { operators need to consider that good quality of service, fairness in } \\
\text { price, pleasant and attractive restaurant the environment can increase } \\
\text { customer satisfaction, which often contributes to customer loyalty. }\end{array}$ \\
\hline
\end{tabular}

\section{OPEN ACCESS}

(C) 2021 The authors, under a Creative Commons Attribution-

NonCommercial 4.0

Corresponding author's email address: danishalikhan763@gmail.com

Recommended citation: Ali, D., Alam, M. \& Bilal, H. (2021). The Influence of Service Quality, Price and Environment on Customer Loyalty in the Restaurant's Industry: The Mediating Role of Customer Satisfaction. Journal of Accounting and Finance in Emerging Economies, 7(1), 143-154

\section{Introduction}

Today more people are dining out as part of the lifestyle, change in environment, food variation, and leisure. The modern living style changes the eating habit and dining out activities. The growing income and level of education seem to influence lifestyle (Shamsudin \& Selamat, 2005). Restaurants are a venue for eating to meet people's social and business activities (Majid et al., 2018). In Pakistan, particularly the capital city Islamabad, dining out has increased, which ultimately expands the town's restaurant business. Evidence showed that the service sector contributes around 60\% in Pakistani GDP and shares $37 \%$ in employment (Pakistan Economic Survey 2017-18-19). The restaurant business has been present in Pakistan since its independence in 1947. Due to the growing population of Pakistan (216.6 million), 
the culinary business is a profitable entrepreneurship therefore rising horizontally and vertically. The changing demographic pattern presents the overview of the upcoming competition. In the food service industry, the competitiveness makes it imperative for businesses to achieve customer satisfaction and also to enjoy long sustainability.

Restaurant executives should be focused on their standard of service, price, and physical environment to compete and produce more substantial revenue. The internal environment and fair price are the primary factors that decide the scale of customer satisfaction (Reimer \& Kuehn, 2005; Ryu \& Jang, 2007). The price and environment can represent the service's quality and even change customers' buying behaviour (Shoemaker et al., 2005). These factors are significant predictors of customer satisfaction (Ryu \& Han, 2010). It is essential to safeguard customer satisfaction because it can contribute to customer loyalty and boost sales. (Ma et al., 2014; Ryu et al., 2012). (Shoemaker \& Lewis, 1999) say that one of the marketing tactics is to retain current customers. Restaurant managers should focus on their marketing strategy, from attracting new customers to sustaining current customers.

Customer loyalty is primarily based on customer satisfaction (McDougall \& Levesque, 2000), Hence after most studies in service marketing concentrated on finding elements that increase customer satisfaction. Studies show that consumer satisfaction is positively affected by service quality, environment, and prices (Ryu, 2005; Varki \& Colgate, 2001). Despite the appearance that physical environment, service quality, price, and customer satisfaction are significant elements in creating customer loyalty, few studies have examined these variables' roles in shaping customer loyalty in service literature. Based on service-related literature, most previous studies analyse the standard of service, customer satisfaction and physical environment in various industries such as the healthcare sector (Yeşilada \& Direktouml, 2010), hotel and resort sector (Ali et al., 2016; Dedeoğlu \& Demirer, 2015), in travel and tourism sector (Debata et al., 2015; Kanwel et al., 2019), the automotive services (Izogo \& Ogba, 2015), airline and public transport industry (Kumar, 2012; Rahim, 2016), and the banking sector (Mohsan et al., 2011). Several researchers have explored different customer satisfaction backgrounds, e.g., the physical environment and price expectations(Ali et al., 2016; Han \& Ryu, 2009; Lee et al., 2014; Wu \& Ko, 2013).

When considering the significance of service quality, restaurant environment, food price, customer satisfaction and Loyalty, limited studies in the service literature (notably in the restaurant industry) have focused on these backgrounds. Nevertheless, none of the prior studies examined service quality, price, and environment to affect customer loyalty through the mediating role of customer satisfaction. As a result, these variables need to be empirically tested for service quality, food prices, and the restaurant environment on the growth of customer satisfaction, leading to Loyalty in the restaurant industry. Furthermore, no empirical study has yet been examined to the extent of service quality, price, and restaurant environment on customer loyalty through the mediating effect of customer satisfaction in the restaurant industry (specifically in Pakistan). Moreover, both empirically and theoretically, the role of food price and restaurant environment in increasing satisfaction and Loyalty remains unclear.

In this study, these elements that makeup customer satisfaction and shape loyalty in the restaurant sector should be empirically assessed. This research focuses on examining how service quality, food price, and restaurant environment can influence user satisfaction. Furthermore, this study also explored the relationship between service quality, price, environment, and customer loyalty through the mediating role of customer satisfaction in the restaurant industry. The study would add to the understanding of the service sector in Pakistan. 


\section{Theoretical framework and hypothesis development \\ 2.1 Service Quality}

The reality that the quality of services is becoming the most significant aspect of competition in the business world is calling the new era of business as the "quality era" (Peeler, 1996). Therefore, several examples of this dilemma have been offered by service marketing experts and researchers. For instance,(Berry \& Parasuraman, 2004) called it the most competitive tool and(Clow \& Vorhies, 1993) called it the organisation's life-giving blood. Service quality in the restaurant is closely linked to how staff performs their duties(Bell et al., 2005).In general, service quality is analysed mostly in customers' experience, relative to their expectations established before service consumption.

Service quality is essential in measuring customer satisfaction (Dandotiya et al., 2020). Customers' purchasing behaviour is closely related to an overall assessment of service or products (Oliver, 1980). The quality of service can significantly affect customer satisfaction, crucial to an organisation's success(Zhong \& Moon, 2020). High quality of service can contribute to enhanced customer satisfaction(Zhao \& Huddleston, 2012). Studies have identified an important relationship among quality of service and customer satisfaction (Loureiro \& González, 2008). Therefore, hypothesis 1 is proposed as:

Hypothesis 1: Service quality has a positive influence on customer satisfaction.

\subsection{Price}

Price is the amount of money paid by customers on goods and services. The amount is the profit of the client's use of goods or services (Zhong \& Moon, 2020). Price is an essential factor that can accumulate satisfaction, as customers often assess the quality of service/ products at its cost (AlMsallam, 2015). Price has a substantial effect on the performance of goods/services; therefore, price disparity could lead to negative behaviours such as shifting brands(Campbell, 1999). It also showed that clients' social expectations about unfair prices could lead to disappointment, decreased repurchases, negative words of mouth, and complaints (Rothenberger, 2015).

Therefore, it can result in undesirable behaviour towards the seller. Many different pricing techniques may be used to boost revenue and create a sense of price fairness at the same time. The pricing strategies' decision is not easy, as they also directly affect revenue, incomes, and customer satisfaction. For the present study, since research has demonstrated that fairness of food price has a substantial influence on the satisfaction of the customers(Konuk, 2018); thus, hypothesis 2 is developed as:

Hypothesis 2: Price has a positive influence on customer satisfaction.

\subsection{Environment of the Restaurant}

In addition to the price and quality of service,the restaurant environment is another factor that can affect customer satisfaction(Padlee et al., 2019). The service literature has documented the effect of the environment on customer satisfaction (Han \& Ryu, 2009; Martín-Ruiz et al., 2012).

The restaurant's impressive architecture also attracts people and directly influences the degree of customer satisfaction. Likewise, a service organisation's environment and ambience often affect customer satisfaction (Han \& Ryu, 2009). (Hanaysha, 2016)The elements, including temperature, lighting, smell, noise, atmosphere, and music, are components of the restaurant environment. Several service literature has studied the physical environment influence on customer satisfaction. (Ali et al., 2016; Mattila \& O’Neill, 2003; Wakerfield \& Blodgett, 1996). Besides, (Marković \& Raspor Janković, 2013) found that higher customer satisfaction was significantly influenced by physical, appearance, equipment, and good communication between staff and guest. (MJ, 1992; Ryu et al., 2012) also emphasised the association among physical atmosphere and customer satisfaction. It is, therefore, hypothesis 3 is proposed as:

Hypothesis 3: Restaurant environment has a significant influence on customer satisfaction. 


\subsection{Customer Satisfaction}

Service providers in any sector strive to satisfy their customer due to their efficiency and revenue (Ali et al., 2016). The concept and importance of customer satisfaction were defined by (Zeithaml et al., 1996) as, to accomplish the long-term continuous success of businesses, the need to reinforce customer satisfaction is a crucial factor. Customer satisfaction can be well described as a detailed service/goods evaluation depend on buying experience and using it over the period (Khadka \& Maharjan, 2017). In contrast to satisfaction, customers' buying intentions have been thoroughly explored in the literature (Ali et al., 2016; Ryu et al., 2012) because it is essential to customer loyalty (Zeithaml et al, 2006).

Service quality, pricing approach, and a comfortable environment are the key elements that influence satisfaction. Restaurants and other service organizations can gain customer satisfaction and Loyalty by providing quality services, fairness in prices, and a friendly environment(Ma et al., 2014; Zhong \& Moon, 2020). According to (Khadka \& Maharjan, 2017), Satisfied customers tend to repurchase the same goods/services, become loyal customers, and are actively involved in recommending to others. Moreover, once consumers are satisfied with goods/services, they would recommend them to others and repurchase the same goods and services in the future(Bennett \& Rundle-Thiele, 2004).

The satisfaction of goods/services greatly influences the intentions to revisit, and if the degree of satisfaction rises, keeping the existing customer is more likely to increase (Zhong \& Moon, 2020). Generally, satisfaction contributes to Loyalty, and Loyalty is a derivative of satisfaction (Khadka \& Maharjan, 2017). Evidence has shown a strong correlation among customers satisfaction and customer loyalty (Leninkumar, 2017). Customers with positive goods/service interaction will continue to deal with the brand in the future because it is less disruptive, make them loyal and adequate in decisionmaking. Several scholars have indicated that customer satisfaction, particularly in the service sector is one of the customer loyalty indicators (Belás \& Gabčová, 2016; Coelho \& Henseler, 2012). According to (Zhong \& Moon, 2020), overall Loyaltyassessed by satisfaction and satisfaction is the crucial Loyalty element. Therefore, the following hypothesis was developed based on the above discussion as:

Hypothesis 4: Customer satisfaction has a significant influence on customer loyalty.

Hypothesis 5: The association between service quality and customer loyalty is mediated by customersatisfaction.

Hypothesis 6: The association between price and customer loyalty is mediated by customersatisfaction.

Hypothesis 7: The association between environment and customer loyalty is mediated by customer satisfaction.

\subsection{Customer Loyalty}

(Oliver, 1999)defined customer loyalty as a willingness to repurchase a preferred good and service repeatedly and recommend to others. Customer loyalty is also important to marketers because it can maintain current customers rather than attracting new customers (Loureiro \& González, 2008). However, Repeated customers minimise marketing costs compared to attract new customers (Shoemaker \& Lewis, 1999). Customer loyalty is an integral part of an organisation's long-term goal(Jin et al., 2013). Notably, loyal customers have a deeper emotional attachment with goods and services (Gounaris \& Stathakopoulos, 2004).A researcher like (Bowen \& Chen, 2001; Dick \& Basu, 1994; Yoo \& Bai, 2013) state that there are three main aspects in determining Loyalty; behaviour (sustained repeat buying/visiting), attitude(psychological and emotional interactions) composite (a combination of these two factors, Loyalty assessed by consumer desires, repeat purchase, positive word of mouth, and willingness to recommend).A customer who intends to repurchase and recommend others has a higher chance of loyalty and stay with the same brand (Kandampully \& Suhartanto, 2000). Thus, in this research, a composite method is utilised to evaluate customer loyalty to the restaurants.

\section{Methods and Materials}




\subsection{Study Design}

Regarding the study design of this research, the primary data was quantitatively obtained by questionnaires. This method allows the researchers to get essential data in a shorter period from a wide range of populations with low cost. In pursuance of answering research questions, questionnaires will be designed to determine respondents' perception of service quality, price, restaurant environment, customer satisfaction, and customer loyalty.Figl illustrates the proposed research model for this study.

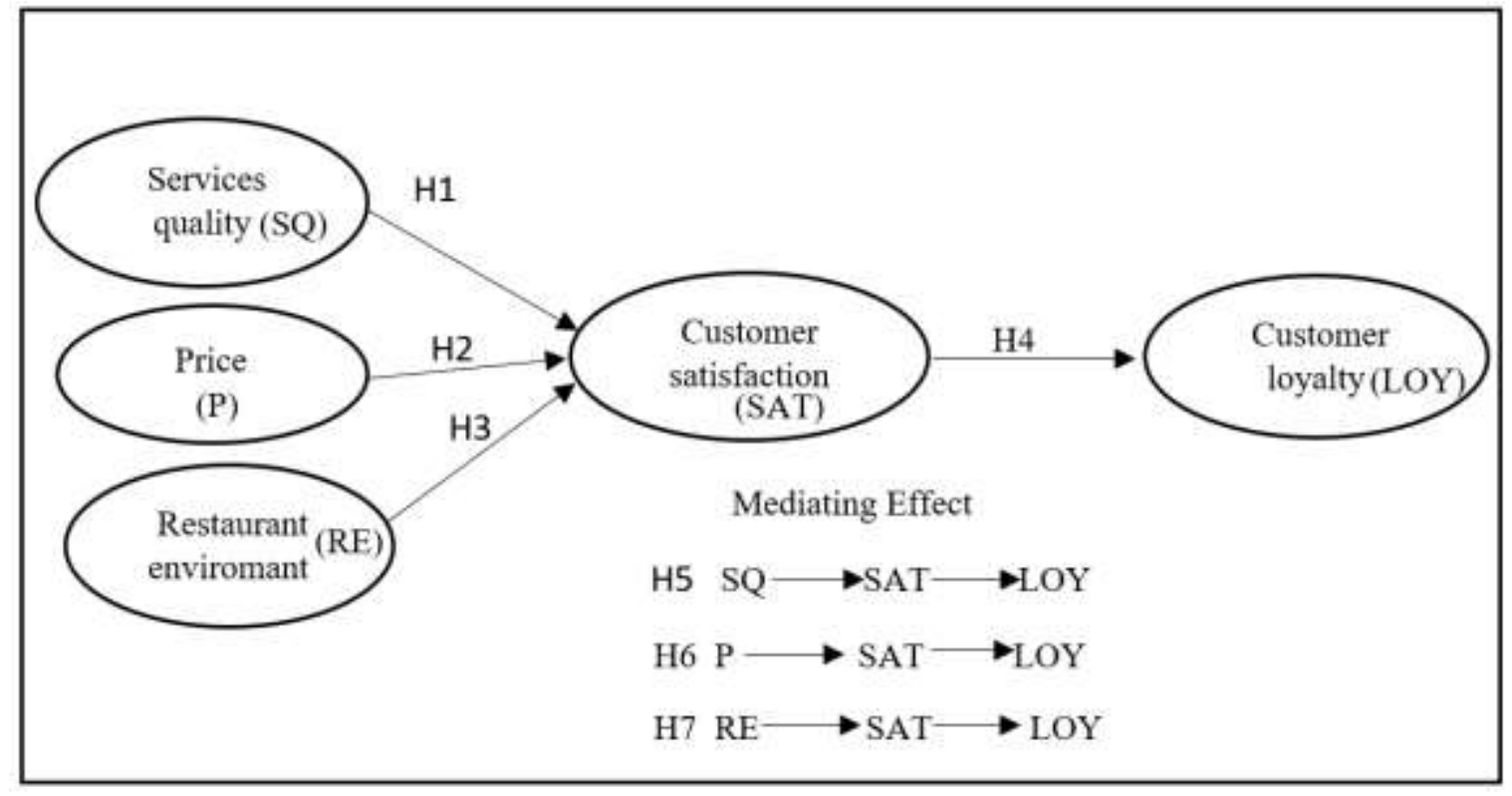

\subsection{Questionnaire Development}

The questionnaire was adapted for this study from previously published research. However, minimal changes were made to make them suitable for this research. The questionnaire was mainly divided into six different sections, and one factor was explored in each section: service quality (SQ), Price (P), Restaurant Environment (RE), Customer Satisfaction (SAT) and customer loyalty. A 5-point Likert scale ranging from 1 (Strongly disagree) and 5 (Strongly agree) were adopted from previous studies. To five factors were quantified discussed above, sixteen (16) items were used (See table 1). Besides, respondent demographic information was also collected, such as gender, marital status, age, education, income, and occupation.

Table 1: Questionnaire and Sources

\begin{tabular}{|c|c|c|}
\hline Variable & Items & Source \\
\hline $\begin{array}{l}\text { Service quality } \\
\text { (SQ) }\end{array}$ & $\begin{array}{c}\text { Staff members are friendly. } \\
\text { Staff members are very helpful. } \\
\text { Staff members serve quickly and promptly. }\end{array}$ & (Zhong \& Moon, 2020) \\
\hline Price $(\mathrm{P})$ & $\begin{array}{c}\text { The price of the food in the restaurant is reasonable } \\
\text { Based on the food, the price here is fair } \\
\text { The price of the food is affordable. }\end{array}$ & (Hanaysha, 2016a) \\
\hline $\begin{array}{l}\text { Restaurant environment } \\
\text { (RE) }\end{array}$ & $\begin{array}{l}\text { The temperature in the restaurant is comfortable. } \\
\text { The restaurant environment is clean. } \\
\text { The colours inside the restaurant are } \\
\text { complementary and coordinating. } \\
\text { The lighting in the restaurant is comfortable. }\end{array}$ & $\begin{array}{l}\text { (Ali et al., 2016; Zhong \& } \\
\text { Moon, 2020) }\end{array}$ \\
\hline $\begin{array}{c}\text { Customer satisfaction } \\
\text { (SAT) }\end{array}$ & $\begin{array}{l}\text { The overall experience of this restaurant is } \\
\text { satisfying. } \\
\text { I think my decision to visit this restaurant was a } \\
\text { wise one. } \\
\text { This restaurant meets most of my expectations. }\end{array}$ & $\begin{array}{l}\text { (Ali et al., 2016; Hanaysha, } \\
\text { 2016b) }\end{array}$ \\
\hline $\begin{array}{l}\text { Customer loyalty } \\
\text { (LOY) }\end{array}$ & $\begin{array}{l}\text { I will continue to visit this restaurant in the future. } \\
\text { I will recommend this restaurant to others. } \\
\text { I will say positive things about this restaurant to } \\
\text { others }\end{array}$ & $\begin{array}{l}\text { (Gong \& Yi, 2018; Zhong \& } \\
\text { Moon, 2020) }\end{array}$ \\
\hline
\end{tabular}




\subsection{Data Collection}

The survey was organised in Pakistan's capital city (Islamabad) through face-to-face contact with customers at different restaurants. A self-administered survey was used to collect the data. Sampling was carried out over three weeks by distributing questionnaires to customers at different restaurants in various Islamabad locations. A convenience sample was drawn for the research. Our study's purpose was clarified to the customer to increase participation, and questionnaires were given only to those who were willing to participate in this research survey. A 500 questionnaires were distributed in total, and 385 were considered appropriately complete after the deletion of incomplete answers, showing a response rate of $77 \%$.

\section{Data Analysis}

We used SPSS v.25 to assess and analysed data for this research. The respondent's demographic information was defined by using descriptive statistics. Multiple regression was used to test the model and the hypotheses systematically. Before multiple regression, each construct's internal consistency was tested to ensure its reliability and validity.

The values in(table 2) showed that $65 \%$ of people surveyed were male, and $34.5 \%$ female, with $57.3 \%$ being single, while $42.7 \%$ were married. Approximately $42.5 \%$ of respondents were $21-25$-year-old, $42.5 \%$ were $26-30,12.2 \%$ were $36-45,5.7 \%$ were under 20 , and just $2.1 \%$ were $46-55$-year-old. $36 \%$ of the total respondents had a master's degree, while $34 \%$ had an undergraduate degree, $17.4 \%$ had a college education, and $10.9 \%$ had a $\mathrm{PhD}$ degree.

Table 2: Demographics Characteristics of the Respondents

\begin{tabular}{|c|c|c|}
\hline Characteristic & & Percentage \\
\hline \multirow{3}{*}{ Gender } & Male & 65.5 \\
\hline & Female & 34.5 \\
\hline & Total & 100 \\
\hline \multirow[t]{3}{*}{ Marital Status } & Single & 57.3 \\
\hline & Married & 42.7 \\
\hline & Total & 100 \\
\hline \multirow{6}{*}{ Age } & 20 year or below & 5.7 \\
\hline & $21-25$ & 42.5 \\
\hline & $26-30$ & 35.5 \\
\hline & $36-45$ & 12.2 \\
\hline & $46-55$ & 2.1 \\
\hline & Total & 100 \\
\hline \multirow{6}{*}{ Education } & Secondary school & 1.6 \\
\hline & College/university & 17.4 \\
\hline & Undergraduate & 34.2 \\
\hline & Master & 36.0 \\
\hline & $\mathrm{PhD}$ & 10.9 \\
\hline & Total & 100 \\
\hline \multirow{7}{*}{ Monthly income PKR } & Less 10,000 & 19.9 \\
\hline & $10,000-19,999$ & 8.5 \\
\hline & $20,000-29,999$ & 10.9 \\
\hline & $30,000-39,000$ & 14.0 \\
\hline & $40,000-49,999$ & 23.8 \\
\hline & More than 50,000 & 22.8 \\
\hline & Total & 100 \\
\hline \multirow{6}{*}{ Occupation } & Government employee & 21.0 \\
\hline & Private sector & 35.0 \\
\hline & Student & 28.5 \\
\hline & Business owner & 11.9 \\
\hline & Housewife & 3.6 \\
\hline & Total & 100 \\
\hline
\end{tabular}




\subsection{Reliability and Validity Test}

This study ensures data validity and reliability through factor analysis and reliability Test. The Cronbach alpha is a common technique for testing the item's internal consistency(Gefen et al., 2000; Manzoor et al., 2019). All variables' alpha values were ranged from 0.884-0.910, which is higher than the recommended 0.70, ensuring the inner consistency construct. In addition, factor analysis was employed using Principal components to report the factor loading. Overall, the loading factor ranged from 0.917 to 0.881 , thus fulfilling the validity.

Table 3: Reliability and Validity Test

\begin{tabular}{lccc}
\hline Constructs & Item & Cronbach Alpha & Factor Loading \\
\hline Service quality & 3 & .884 & .882 \\
Price perception & 3 & .889 & .917 \\
Environment & 4 & .910 & .901 \\
Customer satisfaction & 3 & .898 & .855 \\
Customer loyalty & 3 & .896 & .881 \\
\hline
\end{tabular}

\subsection{Descriptive and Correlation Analysis}

The descriptive statistic and correlation analysis are shown in table 4. The standard deviations (S.D) value from 1.05 to 1.10 and the mean varied from 3.48 to 3.63, respectively. The correlation values among service quality, Price, Restaurant environment, Customer satisfaction, and Customer loyalty are substantial and positive (see Table 4).

Table 4: Descriptive and Correlation Analysis

\begin{tabular}{|c|c|c|c|c|c|c|c|}
\hline & Means & S. D & 1 & 2 & 3 & 4 & 5 \\
\hline Service quality & 3.63 & 1.07 & $\mathbf{1}$ & & & & \\
\hline Price & 3.48 & 1.10 & .506 ** & $\mathbf{1}$ & & & \\
\hline Restaurant Environment & 3.61 & 1.05 & $.632^{* *}$ & $.540^{* *}$ & $\mathbf{1}$ & & \\
\hline Customer satisfaction & 3.50 & 1.09 & $.549^{* *}$ & $.478^{* *}$ & $.514^{* *}$ & 1 & \\
\hline Customer loyalty & 3.65 & 1.09 & $.527^{* *}$ & $.503^{* *}$ & $.497^{* *}$ & $.718^{* *}$ & 1 \\
\hline
\end{tabular}

Significance of correlation: $* * p<0.01 . S . D=$ standard deviation, values on diagonal are correlation values.

\subsection{Hypothesis Testing Results}

To test the proposed hypotheses, Multiple Regression approach was employed. Table 5 And Fig 2 report correlation coefficient $(\beta)$, levels of significance (t-value), and significant effects of 7 hypotheses. All hypotheses are fully supported.

Service quality $(\beta=.560, \mathrm{t}=12.87, \mathrm{p}<0.01)$ was significantly associated with customer satisfaction. Therefore hypothesis 1 is accepted. While price $(\mathrm{P})(\beta=.472, \mathrm{t}=10.67, \mathrm{p}<0.01)$ and restaurant environment $(\beta=.531, \mathrm{t}=11.75, \mathrm{p}<0.01)$ was significantly related with customer satisfaction. Hence the hypothesis 2 and hypothesis 3 are accepted, respectively. H4was projected that SAT is significantly associated with $\operatorname{LOY}(\beta=.721, \mathrm{t}=20.20, \mathrm{p}<0.01)$. Thus, our H4 is accepted, respectively. 
Table 5: Regression coefficient ( $\beta$ ) for testing hypothesis 1-7

\begin{tabular}{lccccccc}
\hline Path & F-Stat & $\begin{array}{c}\text { T- } \\
\text { values }\end{array}$ & S. $\boldsymbol{E}$ & $\boldsymbol{\beta}$ & LL95\%CI & UL95\%CI & P-Value \\
\hline Service quality $\longrightarrow$ Satisfaction & 165.8 & 12.87 & .043 & .560 & & & $* * *$ \\
Price $\longrightarrow$ Satisfaction & 113.8 & 10.67 & .044 & .472 & & & $* * *$ \\
Environment $\longrightarrow$ Satisfaction & 138.1 & 11.75 & .045 & .531 & & & $* * *$ \\
Satisfaction $\longrightarrow$ Loyalty & 408.7 & 20.20 & .036 & .721 & & & $* * *$ \\
SQ $--\rightarrow$ SAF- $\rightarrow$ LOY & & 4.59 & .042 & .3447 & .2668 & .4287 & $* * *$ \\
P $-\longrightarrow$ SAF- $\rightarrow$ LOY & & 5.28 & .0388 & .2933 & .2156 & .3746 & $* * *$ \\
E $\longrightarrow--\rightarrow$ SAF- $-\rightarrow$ LOY & & 4.28 & .0420 & .3350 & .2560 & .4223 & $* * *$ \\
\hline
\end{tabular}

Note: $* * p<0.01$. S.E: Standard error

In addition, the outcome of mediation analysis (see table 5 and Fig 2) shows the indirect effect of $\mathrm{SQ} \rightarrow \mathrm{SAT} \rightarrow$ LOY was positive $(\beta=.344, \mathrm{t}=4.49, \mathrm{p}<0.01)$ thus the H5 is supported. Moreover, the SAT mediates relationship between P and LOY $(\beta=.293, t=5.28, p<0.01)$ H6 is supported. The SAT mediates association among RE and LOY $(\beta=.335, \mathrm{t}=4.28, \mathrm{p}<0.01)$; thus, the H7 is statistically significant and accepted, respectively.

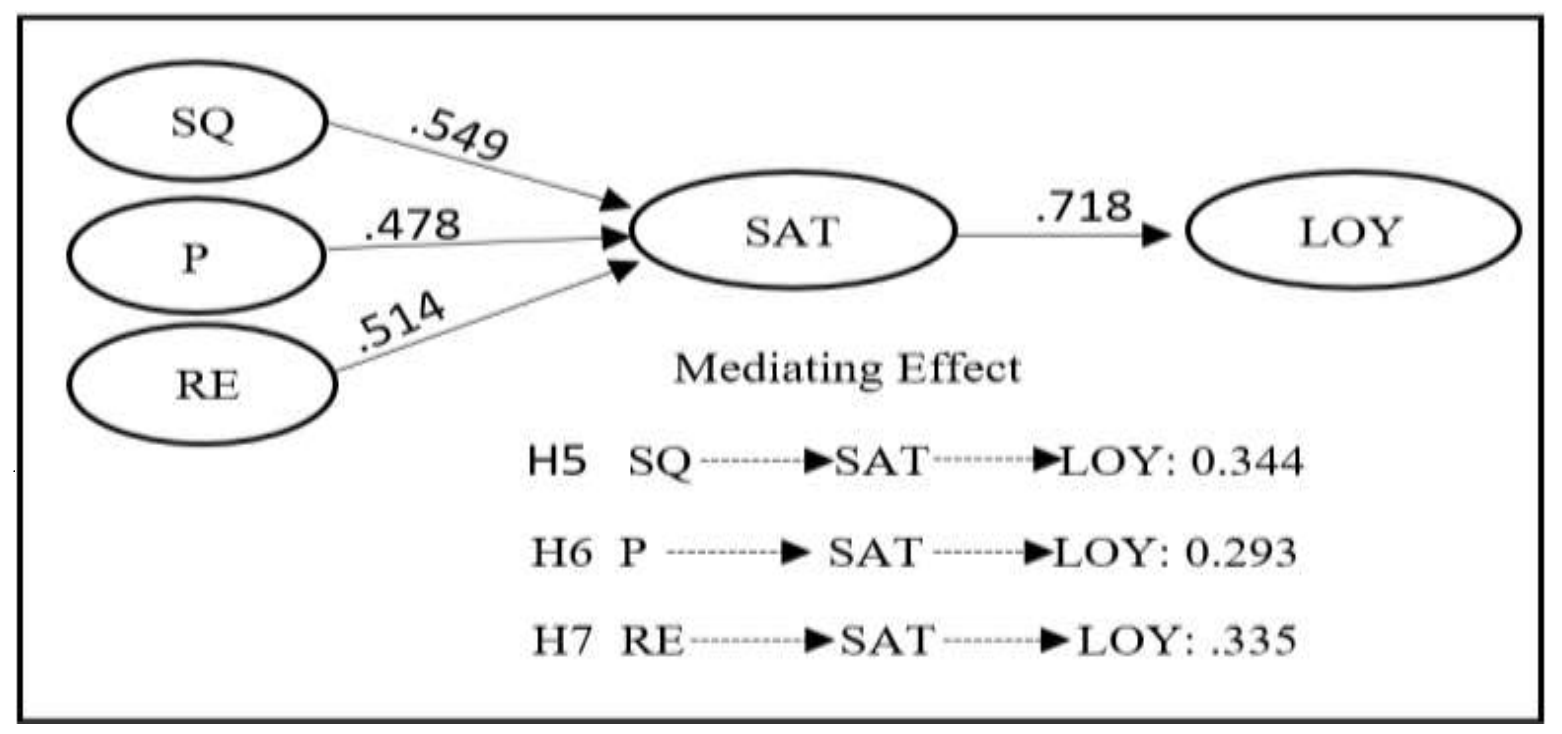

\section{Discussions and Conclusion}

In this research, the association among service quality (SQ), price (P) restaurant environment (RE) on customer loyalty (LOY) has been examined via the mediating effect of customer satisfaction (SAT). The outcome of our research indicates the positive and significant relationship among all variable. Our findings show that the restaurant's SQ and pleasant RE can significantly affect SAT. Beside SQ and RE, Price also has a positive impact on customer satisfaction.

In addition, the association among SAT and LOY is also positive and Significant. Our study outcome indicates that SAT influences LOY. Thus, customer satisfaction is an essential element that keeps a customer loyal in a restaurant. As supported by Oliver (1997), if the actual result meets the requirements, the customer will be satisfied. Moreover, the association between SQ, P, RE and LOYhassignificantly mediated by SAT. The indirect association among quality of service, price, restaurant environment and customer loyalty were positive. Therefore, restaurant operators need to consider their service quality, fairness in price and attractive restaurant environment, to enhance customer satisfaction and Loyalty. Thus, restaurants who have loyal customers must protect them adequately because it can improve a positive word of mouth and suggest the restaurant others.

The factors influencing SAT and LOY were analysed in this paper. Therefore, this research adds to the literature about the elements that influence the SAT and LOY in the restaurant industry, specifically 
Pakistan. This research also provides a practical understanding of elements affecting customer satisfaction and Loyalty (revisit intention). This study concentrated on how service quality, price, and restaurant environment influence SAT and LOY, particularly in Islamabad, Pakistan's capital city. Future Researchers could conduct a study in other regions or nations through this model or add some more variable such as food quality, customer perceived value or socio-cultural variable's effects in mediating these relationships.

\section{Rferences}

Al-Msallam, S. (2015). Customer satisfaction and brand loyalty in the hotel industry. International Journal of Management Sciences and Business Research, 4.

Ali, F., Amin, M., \& Ryu, K. (2016). The role of physical environment, price perceptions, and consumption emotions in developing customer satisfaction in Chinese resort hotels. Journal of Quality Assurance in Hospitality \& Tourism, 17(1), 45-70.

Belás, J., \& Gabčová, L. (2016). The relationship among customer satisfaction, Loyalty and financial performance of commercial banks. Economics and Management.

Bell, S. J., Auh, S., \& Smalley, K. (2005). Customer relationship dynamics: service quality and customer loyalty in the context of varying levels of customer expertise and switching costs. Journal of the Academy of Marketing Science, 33(2), 169-183.

Bennett, R., \& Rundle-Thiele, S. (2004). Customer satisfaction should not be the only goal. Journal of Services Marketing.

Berry, L. L., \& Parasuraman, A. (2004). Marketing services: Competing through quality. Simon and Schuster.

Bowen, J. T., \& Chen, S. (2001). The relationship between customer loyalty and customer satisfaction. International Journal of Contemporary Hospitality Management.

Campbell, M. C. (1999). Perceptions of price unfairness: antecedents and consequences. Journal of Marketing Research, 36(2), 187-199.

Clow, K. E., \& Vorhies, D. W. (1993). Building a competitive advantage for service firms: measurement of consumer expectations of service quality. Journal of Services Marketing.

Coelho, P. S., \& Henseler, J. (2012). Creating customer loyalty through service customization. European Journal of Marketing.

Dandotiya, R., Aggarwal, P., \& Gopal, R. (2020). Impact of Food and Beverage Quality on Passenger Satisfaction in Indian Railways. International Journal of Customer Relationship Marketing and Management (IJCRMM), 11(2), 37-52.

Debata, B. R., Patnaik, B., Mahapatra, S. S., \& Sree, K. (2015). Interrelations of service quality and service loyalty dimensions in medical tourism. Benchmarking: An International Journal.

Dedeoğlu, B. B., \& Demirer, H. (2015). Differences in service quality perceptions of stakeholders in the hotel industry. International Journal of Contemporary Hospitality Management.

Dick, A. S., \& Basu, K. (1994). Customer loyalty: toward an integrated conceptual framework. Journal of the Academy of Marketing Science, 22(2), 99-113.

Gefen, D., Straub, D., \& Boudreau, M.-C. (2000). Structural equation modeling and regression: guidelines for research practice. Commun Assoc Inf Syst, 4, 2-77.

Gounaris, S., \& Stathakopoulos, V. (2004). Antecedents and consequences of brand loyalty: An empirical study. Journal of Brand Management, 11(4), 283-306.

Han, H., \& Ryu, K. (2009). The roles of the physical environment, price perception, and customer satisfaction in determining customer loyalty in the restaurant industry. Journal of Hospitality \& Tourism Research, 33(4), 487-510.

Hanaysha, J. (2016). Testing the effects of food quality, price fairness, and physical environment on customer satisfaction in fast food restaurant industry. Journal of Asian Business Strategy, 6(2), 3140.

Izogo, E. E., \& Ogba, I.-E. (2015). Service quality, customer satisfaction and Loyalty in automobile repair services sector. International Journal of Quality \& Reliability Management.

Jin, N., Line, N. D., \& Goh, B. (2013). Experiential value, relationship quality, and customer loyalty in 
full-service restaurants: The moderating role of gender. Journal of Hospitality Marketing \& Management, 22(7), 679-700.

Kandampully, J., \& Suhartanto, D. (2000). Customer loyalty in the hotel industry: the role of customer satisfaction and image. International Journal of Contemporary Hospitality Management.

Kanwel, S., Lingqiang, Z., Asif, M., Hwang, J., Hussain, A., \& Jameel, A. (2019). The Influence of Destination Image on Tourist Loyalty and Intention to Visit: Testing a Multiple Mediation Approach. Sustainability, 11, 6401. https://doi.org/10.3390/su11226401

Khadka, K., \& Maharjan, S. (2017). Customer satisfaction and customer loyalty.(Graduate thesis). Centria University of Applied Sciences, Finland.

Konuk, F. A. (2018). Price fairness, satisfaction, and trust as antecedents of purchase intentions towards organic food. Journal of Consumer Behaviour, 17(2), 141-148.

Kumar, K. S. (2012). Expectations and perceptions of passengers on service quality with reference to public transport undertakings. IUP Journal of Operations Management, 11(3), 67.

Lee, S., Jin, N., \& Lee, H. (2014). The moderating role of water park service quality, environment, image, and food quality on perceived value and customer loyalty: A South Korean case study. Journal of Quality Assurance in Hospitality \& Tourism, 15(1), 19-43.

Leninkumar, V. (2017). The relationship between customer satisfaction and customer trust on customer loyalty. International Journal of Academic Research in Business and Social Sciences, 7(4), 450465.

Loureiro, S. M. C., \& González, F. J. M. (2008). The importance of quality, satisfaction, trust, and image in relation to rural tourist loyalty. Journal of Travel \& Tourism Marketing, 25(2), 117-136.

Ma, E., QU, H., \& Eliwa, R. A. (2014). Customer loyalty with fine dining: The moderating role of gender. Journal of Hospitality Marketing \& Management, 23(5), 513-535.

Majid, M. A. A., Samsudin, A., Noorkhizan, M. H. I., Zaki, M. I. M., \& Bakar, A. (2018). Service quality, food quality, image and customer loyalty: An empirical study at a hotel restaurant. International Journal of Academic Research in Business and Social Sciences, 8(10), 1432-1446.

Manzoor, F., Wei, L., Bányai, T., Nurunnabi, M., \& Subhan, Q. (2019). An Examination of Sustainable HRM Practices on Job Performance: An Application of Training as a Moderator. Sustainability, 11, 2263. https://doi.org/10.3390/su11082263

Marković, S., \& Raspor Janković, S. (2013). Exploring the relationship between service quality and customer satisfaction in Croatian hotel industry. Tourism and Hospitality Management, 19(2), 149164.

Martín-Ruiz, D., Barroso-Castro, C., \& Rosa-Díaz, I. M. (2012). Creating customer value through service experiences: an empirical study in the hotel industry. Tourism and Hospitality Management, 18(1), 37-53.

Mattila, A. S., \& O'Neill, J. W. (2003). Relationships between hotel room pricing, occupancy, and guest satisfaction: A longitudinal case of a midscale hotel in the United States. Journal of Hospitality \& Tourism Research, 27(3), 328-341.

McDougall, G. H. G., \& Levesque, T. (2000). Customer satisfaction with services: putting perceived value into the equation. Journal of Services Marketing.

MJ, B. (1992). Servicecapes: The impact of physical surroundings on customers an employee. Journal of Marketing, 56(2), 57-71.

Mohsan, F., Nawaz, M. M., Khan, M. S., Shaukat, Z., \& Aslam, N. (2011). Impact of customer satisfaction on customer loyalty and intentions to switch: Evidence from banking sector of Pakistan. International Journal of Business and Social Science, 2(16).

Oliver, R. L. (1980). A cognitive model of the antecedents and consequences of satisfaction decisions. Journal of Marketing Research, 17(4), 460-469.

Oliver, R. L. (1999). Whence consumer loyalty? Journal of Marketing, 63(4_suppl1), 33-44.

Padlee, S. F., Thaw, C. Y., \& Zulkiffli, S. N. (2019). The relationship between service quality, customer satisfaction and behavioural intentions. Tourism and Hospitality Management, 25(1), 121-139.

Pakistan Economic Survey 2017-18. http://www.finance.gov.pk/fb_2017_18.html Pakistan Economic Survey 2018-19. http://www.finance.gov.pk/fb_2018_19.html 
Rahim, A. G. (2016). Perceived service quality and customer loyalty: The mediating effect of passenger satisfaction in the Nigerian Airline Industry. International Journal of Management and Economics, 52(1), 94-117.

Reimer, A., \& Kuehn, R. (2005). The impact of servicescape on quality perception. European Journal of Marketing.

Rothenberger, S. (2015). Fairness through transparency: The influence of price transparency on consumer perceptions of price fairness. Work. Pap. CEB, 15, 1-37.

Ryu, K. (2005). DINESCAPE, emotions, and behavioral intentions in upscale restaurants. Kansas State University.

Ryu, K., \& Han, H. (2010). Influence of the quality of food, service, and physical environment on customer satisfaction and behavioral intention in quick-casual restaurants: Moderating role of perceived price. Journal of Hospitality \& Tourism Research, 34(3), 310-329.

Ryu, K., \& Jang, S. S. (2007). The effect of environmental perceptions on behavioral intentions through emotions: The case of upscale restaurants. Journal of Hospitality \& Tourism Research, 31(1), 5672.

Ryu, K., Lee, H.-R., \& Kim, W. G. (2012). The influence of the quality of the physical environment, food, and service on restaurant image, customer perceived value, customer satisfaction, and behavioral intentions. International Journal of Contemporary Hospitality Management, 24(2), 200223.

Shamsudin, M. N., \& Selamat, J. (2005). Changing retail food sector in Malaysia. PECC Pacific Food System Outlook, 6, 11-13.

Shoemaker, S., Dawson, M., \& Johnson, W. (2005). How to increase menu prices without alienating your customers. International Journal of Contemporary Hospitality Management.

Shoemaker, S., \& Lewis, R. C. (1999). Customer loyalty: the future of hospitality marketing. International Journal of Hospitality Management, 18(4), 345-370.

Varki, S., \& Colgate, M. (2001). The role of price perceptions in an integrated model of behavioral intentions. Journal of Service Research, 3(3), 232-240.

Wakerfield, K. L., \& Blodgett, J. G. (1996). The effect of the servicescape on customers' behavioral intentions in leisure settings. The Journal of Services Marketing, 10(6), 45-61.

Wu, H.-C., \& Ko, Y. J. (2013). Assessment of service quality in the hotel industry. Journal of Quality Assurance in Hospitality \& Tourism, 14(3), 218-244.

Yeşilada, F., \& Direktouml, E. (2010). Health care service quality: A comparison of public and private hospitals. African Journal of Business Management, 4(6), 962-971.

Yoo, M., \& Bai, B. (2013). Customer loyalty marketing research: A comparative approach between hospitality and business journals. International Journal of Hospitality Management, 33, 166-177.

Zeithaml, V.A. and Bitner, M.J. and Gremler, D.D. (2006), Service Marketing: Integrating Customer Focus across the Firm, 4th ed., McGraw-Hill, New York, NY.

Zeithaml, V. A., Berry, L. L., \& Parasuraman, A. (1996). The behavioral consequences of service quality. Journal of Marketing, 60(2), 31-46.

Zhao, J., \& Huddleston, P. (2012). Antecedents of specialty food store loyalty. The International Review of Retail, Distribution and Consumer Research, 22(2), 171-187.

Zhong, Y., \& Moon, H. C. (2020). What Drives Customer Satisfaction, Loyalty, and Happiness in FastFood Restaurants in China? Perceived Price, Service Quality, Food Quality, Physical Environment Quality, and the Moderating Role of Gender. Foods, 9(4), 460. 
